\title{
Strategi Penerapan Metode Think Pair Square Dalam Meningkatkan Kemampuan Melakukan Operasi Hitung Siswa Belajar Matematika
}

\author{
MUHARNI SIREGAR \\ Sekolah Dasar Negeri 023 Pandau Jaya \\ Jln. AR. Rahim IV No. 1 Siak Hulu, Kampar \\ E-mail : muharni@yahoo.com
}

\begin{abstract}
Application of the method pair square think to students in sub discussion arithmetic operations up to three cycles of numbers are expected to continue to increase the ability of students to learn. Action research method with a sample of students and colleagues for observation and analyzed descriptively. Found results show that by applying the method pair think square by dividing the students into groups of four and assigned tasks to all groups and every student to think and do the job themselves.
\end{abstract}

Keywords: Learning Strategies, Methods Think Pair Square, Ability Students

Kegiatan pembelajaran pada dasarnya dilakukan adalah untuk mencapai tujuan pembelajaran yang telah ditetapkan. Untuk mengetahui sejauh mana siswa mencapai tujuan pembelajaran yang telah ditetapkan diperlukan penilaian dengan menggunakan alat ukur tertentu. Bagi seorang guru sangat penting menguasai cara penilaian hasil belajar siswa. Penilaian yang keliru tentu sangat merugikan siswa. Penilaian dalam kegiatan pembelajaran sering disebut juga asesmen. Pengertian asesmen seringkali disamakan dengan evaluasi, padahal keduanya merupakan dua pengertian yang berbeda. Asesmen dilakukan sejak awal sampai dengan akhir pembelajaran, sedangkan evaluasi dilakukan setelah pembelajaran berakhir. Sebelum kegiatan pembelajaran berlangsung, penilaian hasil belajar siswa sudah direncanakan secara matang, sehingga penilaian bisa bersifat obyektif dan menggambarkan penguasaan hasil belajar siswa yang sebenarnya.(Zulfiani, 2010)

Metode mengajar yang guru gunakan dalam setiap kali pertemuan di kelas bukanlah asal pakai, tetapi setelah melalui seleksi yang berkesesuaian dengan perumusan tujuan instruksional khusus.Jarang sekali guru merumuskan tujuan hanya dengan satu rumusan, tetapi pasti guru merumuskan lebih dari satu
tujuan.Oleh sebab itu gurupun menggunakan metode yang lebih dari satu.(Masjoko, 2015)

Metode think pair and share atau metode berpikir berpasangan dan berbagi merupakan suatu cara yang efektif membuat variasi suasana pola diskusi kelas. Dengan asumsi bahwa semua resistasi atau diseluruhan dan seluruh prosedur yang digunakan dalam think pair and share dapat memberi sisiwa banyak waktu berpikir, untuk merespon dan saling membantu. (Handayana, 2014)

Model Think Pair Square ini dapat diterapkan pada mata pelajaran matematika, karena model ini bertujuan agar adanya kerjasama antara guru dan siswa dalam proses pembelajaran sehingga materi pembelajaran yang diajarkan dapat mudah diserap dan dikembangkan oleh siswa dalam belajar. Namun dalam pelajaran matematika khususnya pada sub bahasan Operasi hitung bilangan sampai tiga angka masih belum sesuai dengan kondisi yang terjadi. Dimana dari hasil pre tes yang dilakukan kepada siswa kelas III semester ganjil di SDN 023 Pandau Jaya, KKM yang diharapkan kepada siswa mencapai angka 65 belum tercapai sepenuhnya yakni hanya mencapai rata-rata 58.

Berdasarkan pada uraian di atas, maka pada kesempatan ini saya tertarik 
melakukan penelitian tindakan kelas dengan menerapkan metode pembelajaran think pair square dalam rangka meningkatkan hasil belajar siswa dalam belajar mata pelajaran matematika khususnya sub materi Operasi hitung bilangan sampai tiga angka.

Model pembelajaran TPS terdiri atas lima langkah, dengan tiga langkah utama sebaga ciri khas, yaitu tahap pendahuluan, think, pairs dan penghargaan. Jumanta Handayama (2014), menjelaskan tahap-tahap pembelajaran TPS sebagai berikut:

a. Tahap pendahuluan, awal pembelajaran dimulai dengan penggalian apresepsi sekaligus memotivasi siswa agar terlibat pada aktivitas pembelajaran.pada tahap ini, guru juga menjelaskan aturan main serta menyampaikan batas waktu untuk setiap tahap kegiatan.

b. Tahap think (berpikir secara individual). Proses think pair and share dimulai pada saat guru melakukan demostrasi untuk menggali konsepsi awal siswa. pada tahap ini, siswa diberi batasan waktu oleh guru untuk memikirkan jawabannya secara individual terhadap pertanyaan yang diberikan. Dalam penentuannya, guru harus menentukan pengetahuan dasar siswa dalam menjawab pertanyaan yang diberikan.

c. Tahap pairs (berpasangan dengan teman sebangku). Pada tahap ini, guru mengelompokan siswa secara berpasangan. Guru menentukan bahwa pasangan sesama siswa adalah teman sebangkunya.Hal ini dimaksudkan agar siswa tidak pindah mendekati siswa lain yang pintar dengan meninggalkan teman sebangkunya. Kemudian, siswa mulai bekerja dengan pasangan kerjanya untuk mendiskusikan permasalahan atau pertanyaan yang diajukan oleh guru.Setiap siswa memiliki kesempatan untuk mendiskusikan berbagai kemungkinan jawaban secara bersama.

d. Tahap Share (berbagi jawaban dengan pasangan lain atau seluruh kelas). Pada tahap ini, siswa dapat mempresentasikan jawabannya secara perseorangan atau secara komperatif kepada seluruh kelompok yang ada.Setiap anggota dari setiap kelompok dapat memperoleh nilai dari hasil pemikiran mereka.

e. Tahap penghargaan. Siswa menfapat penghargaan berupa nilai, baik nilai nidividu maupun kelompok. Nilai individu berdasarkan tahap think, sefangkan nilai kelompok berdasarkan tahap pair dan share.

Guru yang baik perlu mempunyai otonomi dalam melakukan penilaian profesional, sehingga sesungguhnya, ia tidak perlu diberitahu apa yang harus dia kerjakan. Ini tidak berarti bahwa ia tidak dapat menerima masukan atau saran dari luar. Saran atau masukan tersebut tetap penting, tetapi gurulah yang menentukan (memberikan professional judgement) atau yang paling tahu apakah masukan/saran tersebut sesuai dengan kelas yang dihadapinya. (Wardani, 2010)

Hasil penelitian menunjukkan bahwa pembelajaran kooperatif dengan pendekatan struktural Think Pair Square dapat meningkatkan hasil belajar siswa. (Isharyadi, 2015); juga didukung oleh Sukmawati penerapan model pembelajaran kooperatif pendekatan Struktural Think Pair Square (TPS) dapat meningkatkan hasil belajar matematika siswa di kelasVIII-4 MTs Al Huda Pekanbaru pada materi pokok Bangun Ruang Sisi Datar. Dengan demikian dapat disimpulkan bahwa Model Kooperatif TPS memberikan dampak positif terhadap prestasi belajar siswa. (Sukmawati \& Sukmawati, 2017)

Guru diharapkan dapat menerapkan model pembelajaran kooperatif tipe Think Pair Square karena model ini dapat meningkatkan pemahaman konsep matematika siswa. 2) Penelitian ini masih terbatas pada pemahaman konsep matematika siswa. Oleh karena itu, diharapkan kepada rekan peneliti selanjutnya untuk dapat melanjutkan penelitian dengan variabel serta pokok bahasan lain.(Yunanda, 2014); tidak terdapat perbedaan basil belajar matematika siswa yang diajar menggunakan model pembelajaran kooperatif teknik think-pair- 
square dengan yang menggunakan metode discovery learning pada pokok bahasan bangun datar segiempat.(Juliah Dayrini, 2008).

Berdasarkan uraian tersebut, dapat dijelaskan bahwa diduga dengan penerapan metode think pair square dapat meningkatkan kemampuan siswa belajar matematika di tingkat sekolah dasar.

\section{METODE}

Jenis penelitian yang digunakan dalam penelitian ini adalah menggunakan penelitian tindakan karena penelitian tindakan kelas adalah merupakan penelitian yang lebih sesuai dengan tugas pokok dan fungsi guru, meningkatkan kualitas pembelajaran, meningkatkan kualitas siswa, serta mencapai tujuan pembelajaran atau pendidikan. Refleksi tindakan yang diperoleh bisa berupa: praktik-praktik sosial atau pendidikan yang dilakukan oleh guru; kemampuan melakukan terhadap praktikpraktik tersebut dan situasi yang melatarbelakangi praktik itu dilaksanakan. Penelitian tindakan kelas dilakukan secara kolaboratif, untuk kemantapan rasional dalam pelaksanaan tugas, serta memperbaiki kondisi tempat praktik pembelajaran sendiri di sekolah.

Subyek dalam penelitian ini ditentukaan berdasarkan pertimbanganpertimbangan tertentu. Pertimbangan yang dimaksudkan di sini adalah pertimbangan keterlaksanaan pembelajaran memperguna kan think pair square dalam pembelajaran materi Operasi hitung bilangan sampai tiga angka. Metode pengumpulan data pada penelitian ini adalah observasi, tes, wawancara dan catatan lapangan. Observasi dilakukan oleh peneliti dan pengamat (teman sejawat). Observasi dalam penelitian ini adalah observasi langsung yaitu peneliti dan pengamat melihat dan mengamati secara langsung kemudian mencatat perilaku dan kejadian yang terjadi pada keadaan yang sebenarnya. Teknik analisis data yang dipergunakan adalah reduksi data, penyajian data, penarikan simpulan, serta verifikasi refleksi.

\section{HASIL}

Hasil penelitian ini terbagi menjadi dua siklus, yang dimulai dari refleksi awal. Refleksi awal dilaksanakaan dengan melakukan pengamatan pendahuluan untuk mengetahui kondisi awal dilakukan oleh pengamat kelas, yakni rekan sejawat. Hasil refleksi awal dipergunakan untuk menetapkan dan merumuskan rencana tindakan yaitu menyusun strategi awal pembelajaran.

Berdasarkan hasil pengamatan pendahuluan ditemukan bahwa selama pembelajaran berlangsung sebagian siswa kurang memiliki sikap mental siswa dalam mengikuti materi pelajaran juga masih belum memuaskan, dimana siswa masih belum fokus mengikuti materi pelajaran dan masih ribut di kelas sehingga terkadang konsentrasi guru dalam mengajar menjadi terganggu. Selain itu siswa masih kurang aktif dalam menanggapi berbagai bentuk pertanyaan yang diajukan oleh guru. Memang diakui bahwa selama ini materi yang diberikan berdasarkan metode pembelajaran ceramah sehingga ada kesan siswa bosan dengan ceramah yang diberikan oleh guru di depan kelas.

Kegiatan pembelajaran Operasi hitung bilangan sampai tiga angka dapat disajikan dengan menggunakan strategi atau pendekatan dan penggunaan think pair squaredan dapat mengatasi permasalahan tersebut, yaitu metode pembelajaran pari think square. Akhirnya kegiatan pembelajaran dapat berjalan dengan wajar, motivasi belajar siswa meningkat, dan pada akhirnya pestasi belajar siswa meningkat.

Berdasarkan pengamatan awal yang dilakukan oleh guru yang bertindak sebagai peneliti, pada saat berlangsungnya proses pembelajaran diperoleh data kondisi dan permasalahan pembelajaran yang terjadi pada siswa kelas III SDN 023 Pandau Jaya kurang mampu mengingat pelajaran Operasi hitung bilangan sampai tiga angka sehingga siswa memiliki hasil belajar yang rendah.

Berdasarkan kondisi yang ada, maka peneliti merencanakan pembelajaran

p.ISSN: $2407-800 X \quad$ e.ISSN: 2541-4356 
dengan think pair square, agar siswa mampu mengingat yang terjadi pada Operasi hitung bilangan sampai tiga angka dari penjelasan yang diberikan oleh guru di depan kelas dan dari buku pelajaran matematika Kelas III, sehingga prestasi belajarnya meningkat.

Pembelajaran dengan think pair square menekankan pada kegiatan aktif siswa, karena semua siswa terlibat dalam pembelajaran. Guru membagi siswa dalam kelompok berempat dan memberikan tugas kepada semua kelompok, kemudian setiap siswa memikirkan dan mengerjakan tugas tersebut sendiri. Siswa berpasangan dengan salah satu rekan dalam kelompok dan berdiskusi dengan pasangannya dan selanjutnya kedua pasangan bertemu kembali dalam kelompok berempat. Siswa mempunyai kesempatan untuk membagikan hasil kerjanya kepada kelompok berempat.

Berdasarkan hasil pengamatan menunjukkan bahwa selama kegiatan belajar mengajar pada siklus pertama tanggapan siswa dalam memperhatikan penjelasan umum tentang metode pair think square dengan kategori cukup, keterlibatan siswa dalam memikirkan jawaban juga dalam kategori baik, keberanian siswa dalam mencari rekan yang cocok juga baik, keberanian siswa dalam mendeskripsikan Operasi hitung bilangan sampai tiga angka masih cukup dan kecepatan siswa dalam menyelesaikan pertanyaan juga cukup.

Gambar 1: Siklus Tindakan

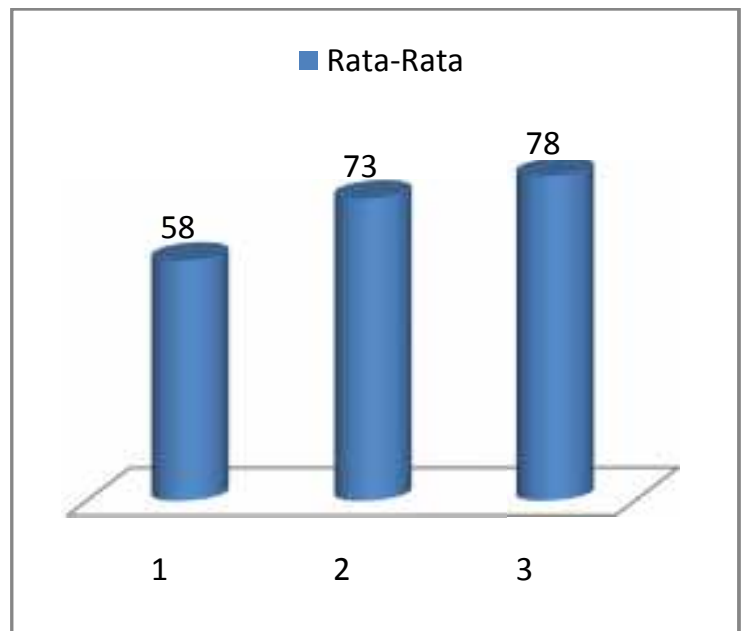

Selama kegiatan belajar mengajar pada siklus kedua tanggapan siswa dalam memperhatikan penjelasan umum tentang metode pair think square dengan kategori baik, keterlibatan siswa dalam memikirkan jawaban juga dalam kategori baik, keberanian siswa dalam mencari rekan yang cocok juga cukup, keberanian siswa dalam mendeskrekonomiikan Operasi hitung bilangan sampai tiga angka baik dan kecepatan siswa dalam menyelesaikan pertanyaan juga baik.

Dalam pelaksanaan penelitian aktivitas guru yang diamati antara lain: (a) pembukaan yang meliputi motivasi dan persepsi, (b) Perangkat pembelajaran yang meliputi penguasaan materi, sistematika penyampaian tugas pada siswa, kejelasan dalam pemberian konsep, kesesuaian media yang dipergunakan, pengelolaan kelas, penggunaan papan tulis, komunikasi yang ditimbulkan, serta ada tidaknya penghargaan kepada siswa, (c) Penampilan guru yang meliputi suara guru harus dapat didengar dengan jelas, guru berpakaian bersih rapi dan sopan, mobilitas guru, serta ekspresi guru, (d) Penutup yang meliputi rangkuman materi yang disampaikan guru, postes, serta cara menutup pembelajaran.

Berdasarkan hasil pengamatan menunjukkan bahwa selama kegiatan belajar mengajar aktivitas guru selama siklus pertama dan kedua yang diamati antara lain: (a) pembukaan yang meliputi motivasi dan persepsi berkriteria baik, (b) Perangkat pembelajaran yang meliputi penguasaan materi, sistematika penyampaian tugas pada siswa, kejelasan dalam pemberian konsep, kesesuaian metode yang dipergunakan, pengelolaan kelas, penggunaan papan tulis, komunikasi yang ditimbulkan, serta ada tidaknya penghargaan kepada siswa berkriteria cukup, (c) Penampilan guru yang meliputi suara guru harus dapat didengar dengan jelas berkriteria baik, guru berpakaian bersih rapi dan sopan berkriteria baik, mobilitas guru berkriteria baik, serta ekspresi guru berkriteria baik, (d) Penutup yang meliputi rangkuman materi yang disampaikan guru, postes, serta cara menutup pembelajaran berkriteria baik. 


\section{PEMBAHASAN}

Pada kegiatan awal guru perlu terusmenerus memotivasi siswa agar aktif selama pembelajaran dengan memberikan penjelasan secara terus menerus mengenai Operasi hitung bilangan sampai tiga angka khususnya pada sub materi pengertian dan kurun waktu pra aksara, kemudian jenis manusia Indonesia yang hidup pada Operasi hitung bilangan sampai tiga angka dan perkembangan kehidupan masa para aksara. Setelah guru membagi siswa dalam kelompok berempat dan memberikan tugas kepada semua kelompok, kemudian setiap siswa memikirkan dan mengerjakan tugas tersebut sendiri. Siswa berpasangan dengan salah satu rekan dalam kelompok dan berdiskusi dengan pasangannya dan selanjutnya kedua pasangan bertemu kembali dalam kelompok berempat. Siswa mempunyai kesempatan untuk membagikan hasil kerjanya kepada kelompok berempat.

Siswa melakukan kegiatan pembagian kelompok dan mendiskusikan pertanyaan kepada pasangan kelompok, sebagian ada yang mampu menyelesaikannya pada waktu yang ditentukan namun sebagian lainnya masih terlambat sehingga dalam penilaiannya masih belum maksimal dan capaiannya masih belum memadai karena siswa masih belum memahami secara baik metode yang diterapkan kepadanya. Berdasarkan pengamatan, siswa dalam pembelajaran pada siklus pertama kkm 65 dan pada siklus I yang sudah tuntas ada $(41,7)$ dengan rata-rata capaian 58.

Pada siklus kedua guru harus lebih semangat kepada siswa untuk lebih berhasil, agar ketuntasan tercapai maksimal. Pada kegiatan mencari jawaban yang paling benar, hafalan terhadap penjelasan guru perlu lebih ditingkatkan dengan cara memberi penjelasan yang lebih mendetail sehingga jawaban dari soal lebih dapat dengan mudah dihafalkannya. Setiap siswa diberi kesempatan bertanya dan mengemukakan pendapat agar mereka lebih hafal dalam memberikan jawaban dari pertanyaan pada kartu yang diberikan. Berdasarkan pengamatan, siswa dalam pembelajaran pada siklus kedua KKM 65dan pada siklus kedua yang tuntas ada $(79,2 \%)$.

Pada siklus ketiga guru harus lebih semangat kepada siswa untuk lebih berhasil, agar ketuntasan tercapai maksimal. Pada kegiatan mencari jawaban yang paling benar, hafalan terhadap penjelasan guru perlu lebih ditingkatkan dengan cara memberi penjelasan yang lebih mendetail sehingga jawaban dari soal lebih dapat dengan mudah dihafalkannya. Setiap siswa diberi kesempatan bertanya dan mengemukakan pendapat agar mereka lebih hafal dalam memberikan jawaban dari pertanyaan pada kartu yang diberikan. Hasil belajar siswa pada siklus kedua tampak pada tabel di bawah ini:

Berdasarkan pengamatan, siswa dalam pembelajaran pada siklus ketiga KKM 65 dan pada siklus kedua yang tuntas ada $87,5 \%$. Dalam pelaksanaan penelitian tindakan kelas pada materi Operasi hitung bilangan sampai tiga angka siswa yang diamati meliputi tanggapan siswa dalam memperhatikan penjelasan umum tentang metode pair think square, keterlibatan siswa dalam memikirkan jawaban, keberanian siswa dalam mencari pasangan dalam kelompok yang telah ditentukan, keberanian siswa dalam mendeskrekonomiikan Operasi hitung bilangan sampai tiga angka dan kecepatan siswa dalam menyelesaikan pertanyaan

Sejalan dengan hasil penelitian Sumaryati bahwa kemampuan pemahaman dan kemampuan berpikir krtis matematis siswa yang mendapat pembelajaran dengan pendekatan induktif-deduktif disertai dengan strategi Think-Pair-Square-Share tergolong sedang dan kemampuan matematis siswa yang memperoleh pembelajaran biasa tergolong kurang. Namun ditemukan tidak terdapat perbedaan disposisi matematis pada kedua kelas, dan diposisi matematis tersebut tergolong sedang. Selain itu, studi juga menemukan terdapat asosiasi yang lemah antar kemampuan pemahaman, berpikir kritis, dan disposisi matematis. Namun siswa

$$
\text { p.ISSN: } 2407-800 X \quad \text { e.ISSN: 2541-4356 }
$$


menunjukkan pendapat yang positif terhadap pembelajaran dengan pendekatan induktifdeduktif disertai strategi Think-Pair-SquareShare.(Enung Sumaryati 1), 2013)

Juga hasil penelitian Karyawati bahwa data yang dikumpulkan dianalisis dengan menggunakan analisis statistik deskriptif dan statistik inferensial (uji- $t$ sample independent). Berdasarkan hasil analisis data, diperoleh thit $=7,94$ dan ttab (pada taraf signifikansi 5\%) $=1,658$. Hal ini berarti bahwa thit > ttab, sehingga dapat diinterpretasikan bahwa terdapat perbedaan hasil belajar Matematika siswa yang signifikan antara kelompok yang mengikuti pembelajaran dengan model pembelajaran kooperatif tipe think pair square berbantuan kartu kerja dan kelompok yang mengikuti pembelajaran dengan model pembelajaran konvensional. Berdasarkan hasil penelitian ini dapat disimpulkan bahwa penerapan model pembelajaran kooperatif tipe think pair square berpengaruh positif terhadap hasil belajar Matematika siswa kelas V di Gugus I Nakula Kecamatan Negara.(Karyawati, 2014)

Hasil penelitian Tresnayanti bahwa: (1) terdapat perbedaan motivasi berprestasi secara signifikan antara siswa yang mengikuti model pembelajaran Think Pair Square dan siswa yang mengikuti pembelajaran konvensional, (2) terdapat perbedaan prestasi belajar IPS secara signifikan antara siswa yang mengikuti model pembelajaran Think Pair Square dengan siswa yang mengikuti pembelajaran konvensional, (3) terdapat perbedaan motivasi berprestasi dan prestasi belajar secara simultan antara siswa yang mengikuti model pembelajaran Think Pair Square dan siswa yang mengikuti pembelajaran konvensional.(Tresnayanti, 2013)

Hasil penelitian Oktaviani menunjukkan bahwa rata-rata interaksi siswa dengan siswa maupun interaksi siswa dengan guru pada siklus I sebesar $64,34 \%$ dengan kategori sedang dan rata-rata interaksi siswa dengan siswa maupun interaksi siswa dengan guru pada siklus II sebesar 75,23\% dengan kategori tinggi. (OKTAVIANI, 2016)

Jurnal Daya Saing
Pembagian waktu dalam tahap Think-Pair-Square direncanakan dengan cermat agar waktu pembelajaran efektif. Siswa perlu diberikan waktu lebih pada berpikir sendiri dan diskusi berpasangan agar hasil belajar optimal.(Primandari, 2010).

Dari uraian hasil penelitian dan dikaitkan dengan penelitian terdahulu, maka dapat dikatakan penelitian ini mendukung dan mengembangkan penelitian sebelumnya dalam pelajaran matematika di sekolah dasar.

\section{SIMPULAN}

Setelah penerapan metode pair think square kepada siswa pada sub bahasan operasi hitung bilangan sampai tiga angka terus mengalami peningkatan. Melalui penerapan metode pair think square dengan membagi siswa dalam kelompok berempat dan memberikan tugas kepada semua kelompok dan setiap siswa memikirkan dan mengerjakan tugas tersebut sendiri. Lalu siswa berpasangan dengan salah satu rekan dalam kelompok dan berdiskusi dengan pasangannya. Kemudian kedua pasangan bertemu kembali dalam kelompok berempat dan siswa mempunyai kesempatan untuk membagikan hasil kerjanya kepada kelompok berempat berhasil meningkatkan hasil belajar siswa.

\section{DAFTAR RUJUKAN}

\section{Jumanta Handayama, Model dan Metode Pembelajaran Kreatif dan berkarkrakter, (Jakarta: Ghalia Indonesia, 2014), h. 201}

Enung sumaryati 1). (2013). Pendekatan induktif-deduktif disertai strategi think-pair-square-share untuk meningkatkan kemampuan pemahaman dan berpikir kritis serta disposisi matematis siswa sma. Infinity, 2(1), 26-42.

Isharyadi, r. (2015). Penerapan model pembelajaran kooperatif pendekatan

p.ISSN: 2407-800X e.ISSN: 2541-4356 
struktural think pair square untuk meningkatkan hasil belajar matematika siswa kelas vii 10 smp negeri 13 pekanbaru. Jurnal ilmiah edu research, 4(1), 71-78.

Juliah dayrini. (2008). Perbandingan hasil belajar mate $\backslash$ Iatika.siswa antara yang diajar menggunakan $\quad$ :iodel peiwbelajaran kooperatif teknik tlf/nkpair-squaredengan yang menggl!nakan metode discovery learning (stu di kasus di smp negeri 169 jakarta barat).

Karyawati, n. K. (2014). Pengaruh model pembelajaran kooperatif tipe think pair square ( tps ) berbantuan kartu kerja terhadap hasil belajar matematika. Jurnal mimbar, 2(1).

Masjoko. (2015). Metode belajar mengajar.

Oktaviani, a. B. (2016). Peningkatan interaksi dalam pembelajaran matematika melalui model pembelajaran kooperatif tipe think-pair-square (tps) pada siswa kelas iv sdn pule $i$.

Primandari, a. H. (2010). Upayameningkatkan kemampuan pemecahanmasalah siswakelas viiia smp n 2 nanggulan dalampembelajaranmatematika pokok bahasan bangun ruang menggunakanmodel pembelajaran kooperatif tipe think-pair-square.

Sukmawati, s., \& sukmawati, s. (2017). Penerapan model pembelajaran kooperatif pendekatan struktural think pair square untuk meningkatkan hasil belajar matematika siswa, 10 .

Tresnayanti, n. M. D. (2013). Pengaruh model pembelajaran think pair square terhadap motivasi berprestasi dan prestasi belajar ips siswa kelas vii smp negeri 3 singaraja, $3(2)$.
Wardani, k. (2010). Hakikat penelitian tindakan kelas, 1-36.

Yunanda, m. S. (2014). Pengaruh pembelajaran kooperatif tipe think pair square terhadap pemahaman konsep matematika siswa kelas xi ipa sma adabiah padang. Jurnal pendidikan matematika, 3(3), 5-10.

Zulfiani. (2010). Strategi pembelajaran sains. 